\title{
Assessment of kinetics behavior of electrocoagulation process for the removal of suspended solids and metals from synthetic water
}

\author{
Hariraj Singh, Brijesh Kumar Mishra ${ }^{\dagger}$ \\ Department of Environmental Science and Engineering, Indian Institute of Technology (ISM) Dhanbad, Jharkhand 826004, India
}

\begin{abstract}
Globalization, industrialization, mining, and uncontrolled population growth have fostered a shortage of potable water. Therefore, it has become imperative to understand an effective and reasonable water purification technique. A renewed interest in electrocoagulation (EC) has been spurred by the search for reliable, cost-effective, water-treatment processes. This paper has elucidated a technical approach for getting rid of heavy metals and total suspended solids (TSS) from synthetic water using an aluminum electrode. The effect of operational parameters, such as current density, inter-electrode distance, operating time, and $\mathrm{pH}$, were studied and evaluated for maximum efficiency. This study corroborates the correlation between current density and removal efficiency. Neutral $\mathrm{pH}$ and a low electrode gap have been found to aid the efficacy of the EC setup. The outcome indicates that a maximum TSS removal efficiency of $76.6 \%$ occurred at a current density of $5.3 \mathrm{~mA} / \mathrm{cm}^{2}$ during a contact time of $30 \mathrm{~min}$. In the case of heavy metals remediation, $40 \mathrm{~min}$ of process time exhibited extremely reduced rates of $99 \%$, $59.2 \%$, and $82.1 \%$, for $\mathrm{Cu}, \mathrm{Cr}$, and $\mathrm{Zn}$, respectively. Moreover, kinetic study has also demonstrated that pollutants removal follows first-and second-order model with current density and EC time being dependent.
\end{abstract}

Keywords: Current density, Electro-coagulation, Heavy metals, Kinetic, Synthetic water

\section{Introduction}

The explosive population increase and expansion of urban areas have exacerbated adverse impacts on water resources [1, 2]. Nowadays, Mining and industries have been found to produce significant contributions in accelerating extent of contamination in the surroundings. Mine water and Industrial effluents are known antecedent of heavy metals. Doubtless, it has deteriorated water quality by incorporating a high absorption of toxic metals. The repercussions of metallic contaminants like $\mathrm{Pb}, \mathrm{Cr}, \mathrm{Zn}$ and $\mathrm{Cu}$ on the wide application of water have been scrutinized and it has been recommended to treat contaminated water before discharging. Thus, there is an exigency to develop effective and economical water purification technique to curtail its deleterious effects.

The right of all people to access suitable water supplies must thus be seen as a global challenge, the solution of which is dependent on the formulation and implementation of sustainable water management strategies. To resolve this problem, technical approaches such as ion exchange chromatography, ultrafiltration, reverse osmosis and chemical precipitation have been applied. But each treatment method comes with their respective pros and cons. For example, Ion exchange chromatography is highly effective in removing certain charged contaminants, but it requires costly resin regeneration. Ultra filtration and reverse osmosis are clean processes, merely they are prohibitively expensive. Chemical precipitation is a simple procedure; it does get a high volume of sludge.

Researchers have explored different innovative approaches to unfold eco-friendly heavy metals remediation. Studies have revealed electrocoagulation (EC) as one of the efficient and cost effective technique for the removal of heavy metals. This technique relies on the principal of segregating heavy metals in the presence of electric current using suitable electrodes [3-5]. In this process, Iron is the most widely used electrode followed by aluminum. When aluminum is used as anodes, it produces aluminum hydrox-
This is an Open Access article distributed under the terms of the Creative Commons Attribution Non-Commercial License (http://creativecommons.org/licenses/by-nc/3.0/) which permits unrestricted non-commercial use, distribution, and reproduction in any medium, provided the original work is properly cited.
Received February 18, 2016 Accepted October 17, 2016

${ }^{\dagger}$ Corresponding author

Email: bkmishra3@rediffmail.com

Tel: +91-947-1191704 Fax: +91-326-2296624

Copyright (C) 2017 Korean Society of Environmental Engineers 
ide, $\mathrm{Al}(\mathrm{OH})_{3}$, upon oxidation in an electrolytic system [6].

Table 1 shows the values of EC parameters chosen by some authors [4, 7-10] for the removal of heavy metal using aluminum or iron electrodes. The parameters, whose values will be compared with this work (Table 1), are: Conductivity and electrolyte composition; initial $\mathrm{pH}$; number of metals present in the medium and initial metal concentrations; the volume of the solution investigated; number of electrodes used; total electrode surface area and distance between electrodes; current density; operating time. As indicated in Table 1, EC is usually taken using high electrolyte conductivity (from 1.5 to $20 \mathrm{mS} / \mathrm{cm}$ ). High conductivity can be obtained with the addition of salts like $\mathrm{NaCl}, \mathrm{NaNO}_{3}$ and $\mathrm{Na}_{2} \mathrm{SO}_{4}$ $[7,8]$. The role of salt addition is to lower the electrolysis potential and, in the case of chloride ions, to enhance anodic dissolution of the electrodes.

Metals and total suspended solids (TSS) removal through the EC process is well known, but optimization of the EC process with reference to energy requirement and percentage removal has not yet been studied in detail. The aim of the present study was to understand the various factors affecting removal efficiency of metals and TSS by EC process with reference to energy requirement to understand the feasibility of EC process.

\section{Materials and Methods}

\subsection{Reagents and Solutions}

Reagents were prepared using distilled demineralized water from the Mili-Q water system. Titrisol Merck standard solutions of 1,000 $\mathrm{mg} / \mathrm{L}$ of copper, chromium, and zinc were used and solutions of different concentrations were obtained by adequate dilutions. The $\mathrm{pH}$ of the solution was adjusted by $0.1 \mathrm{~N} \mathrm{HCl}$ and $0.1 \mathrm{~N}$ $\mathrm{NaOH}$ solutions prepared from AR grade Merck chemicals.

Table 1. Comparisons of Treatment Performances of Different Wastewater with Process Conditions and Variables in the EC Process

\begin{tabular}{|c|c|c|c|c|c|c|}
\hline Reference & [7] & [8] & [9] & [4] & [10] & $\begin{array}{l}\text { This study } \\
\text { conditions }\end{array}$ \\
\hline Kind of water & Synth. Water & Synth. Water & $\begin{array}{l}\text { Metal plating } \\
\text { wastewater }\end{array}$ & Synth. Water & $\begin{array}{c}\text { Grenhole ground } \\
\text { water }\end{array}$ & Synth. Water \\
\hline $\begin{array}{l}\text { Conductivity } \\
(\mathrm{mS} / \mathrm{cm})\end{array}$ & 20 & $1.7-2.9$ & 2 & 1.47 & 0.35 & $0.62\left(21.3^{\circ} \mathrm{C}\right)$ \\
\hline Initial $\mathrm{pH}$ & $4.5-7.5$ & 4.9 & 3 & $3 ; 5.68 ; 8.95$ & 7.7 & $\begin{array}{c}3.2 \\
\text { (7 after addition of } \\
\mathrm{NaOH})\end{array}$ \\
\hline $\begin{array}{l}\text { Metal concentration } \\
(\mathrm{ppm})\end{array}$ & $\begin{array}{ll}\mathrm{Cu}^{2+} & 50-250 \\
\mathrm{Zn}^{2+} & 50-5000 \\
\mathrm{Ni}^{2+} & 50-250 \\
\mathrm{Cr}(\mathrm{VI}) & 10-50 \\
\mathrm{Ag}^{+} & 5-50\end{array}$ & $\begin{array}{ll}\mathrm{Cu}^{2+} & 59 \\
\mathrm{Zn}^{2+} & 67 \\
\mathrm{Ni}^{2+} & 67\end{array}$ & $\begin{array}{l}\mathrm{Cu}^{2+} 45 \mathrm{Cr}(\mathrm{VI}) 44.5 \\
\mathrm{Ni}^{2+} 394\end{array}$ & $\begin{array}{ll}\mathrm{Cu}^{2+} & 50-250 \\
\mathrm{Zn}^{2+} & 50-250 \\
\mathrm{Ni}^{2+} & 50-250 \\
\mathrm{Mn}^{2+} & 50-250\end{array}$ & $\begin{array}{ll}\mathrm{Cu}^{2+} & 12 \\
\mathrm{Zn}^{2+} & 20 \\
\mathrm{Ni}^{2+} & 20\end{array}$ & $\begin{array}{ll}\mathrm{Cu}^{2+} & 10 \\
\mathrm{Cr}^{6+} & 10 \\
\mathrm{Zn}^{2+} & 10\end{array}$ \\
\hline Treated volume (L) & 1.2 & 0.9 & 0.65 & 0.5 & 15 & 7 \\
\hline $\begin{array}{l}\text { Number of electrode } \\
\text { used }\end{array}$ & 4 & 2 & 6 & 6 & 4 & 2 \\
\hline Electrode material & $\mathrm{Al}$ & $\mathrm{Al}$ & $\mathrm{Al}$ or $\mathrm{Fe}$ & $\mathrm{Fe}$ & $\mathrm{Al}$ or $\mathrm{Fe}$ & $\mathrm{Al}$ \\
\hline $\begin{array}{l}\text { Interelectrode } \\
\text { Distance } d(\mathrm{~mm})\end{array}$ & 5 & 40 & 10 & 3 & 15 & 30 \\
\hline $\begin{array}{l}\text { Anodic surface } \\
\text { area } S\left(\mathrm{~cm}^{2}\right)\end{array}$ & 300 & 54 & 200 & 100 & 720 & 113 \\
\hline $\begin{array}{l}\text { Ratio d/S } \\
\mathrm{cm}^{-1}\end{array}$ & 0.002 & 0.074 & 0.005 & 0.003 & 0.002 & 0.017 \\
\hline Current $I$ (A) & $0.3-3$ & $0.27-1.08$ & $0.5-2$ & $0.2-2.5$ & $0.5-1$ & $0.15-0.6$ \\
\hline $\begin{array}{l}\text { Current density } \\
\left(\mathrm{A} / \mathrm{m}^{2}\right)\end{array}$ & $16-98$ & $50-200$ & $25-100$ & $20-250$ & $7-14$ & $13-53$ \\
\hline Voltage $U(\mathrm{~V})$ & - & 7- 22 & - & 11.75 & $4-10.5$ & $6.3-16.6$ \\
\hline $\begin{array}{l}\text { Treatment time } t \\
(\min )\end{array}$ & $0-140$ & $0-80$ & $0-60$ & $0-50$ & $0-180$ & $0-40$ \\
\hline $\begin{array}{l}\text { Energy consumption } \\
\text { U.I.T/V }\left(\mathrm{kW} \mathrm{h} \mathrm{m} \mathrm{m}^{-3}\right)\end{array}$ & - & $\begin{array}{c}45 \\
\text { (calculated } \\
\text { from the data at } \\
\mathrm{I}=1 \mathrm{~A} \text { and } \\
\mathrm{t}=60 \mathrm{~min} \text { ) }\end{array}$ & $\begin{array}{c}2 \\
\text { (at } \mathrm{I}=1 \mathrm{~A} \text { and } \\
\mathrm{t}=15 \mathrm{~min})\end{array}$ & $\begin{array}{c}49 \\
\text { (at } \mathrm{I}=2.5 \mathrm{~A} \text { and } \\
\mathrm{t}=50 \mathrm{~min} \text { ) }\end{array}$ & $\begin{array}{c}0.6 \text { and } 0.59 \\
\text { (at } \mathrm{I}=1 \mathrm{~A} \text { and } \\
\mathrm{t}=60 \text { min with } \\
\text { Fe respectively } \\
\text { Al electrodes) }\end{array}$ & $\begin{array}{c}0.459 \\
\text { (at } \mathrm{I}=0.450 \mathrm{~A} \text { and } \\
\text { time } 30 \mathrm{~min} \text { ) }\end{array}$ \\
\hline
\end{tabular}


$\mathrm{CuSO}_{4} \cdot 5 \mathrm{H}_{2} \mathrm{O}, \mathrm{K}_{2} \mathrm{Cr}_{2} \mathrm{O}_{7}$, and $\mathrm{ZnO}$ were used in the present study for preparing of $\mathrm{Cu}, \mathrm{Cr}$ and $\mathrm{Zn}$ based synthetic water. A measured quantity of $1 \mathrm{~L}$ of freshly prepared synthetic solution of $\mathrm{Cu}, \mathrm{Cr}$ and Zn using tap water was taken in EC process.

\subsection{Experimental Setup and Procedure}

A Perspex made reactor (Table 2) having specific dimension 250 $\mathrm{mm} \times 250 \mathrm{~mm} \times 300 \mathrm{~mm}$ was used to carry out remediation of heavy metals as a batch type to conduct the experiments. Good quality metal sheets of aluminum used as electrodes of $150 \mathrm{~mm}$ $\times 250 \mathrm{~mm} \times 2 \mathrm{~mm}$ size for EC. The sufficient gap between the anode and cathode was varied as per requirement. The reactor is constructed in such a style; it could be adjusted horizontally as well as vertically as needed.

The experimental setup is shown in Fig. 1 for the EC experiments, Aluminum (Al) plates with $2 \mathrm{~mm}$ thickness were used, and the surface area in contact with the electrolyte was in each case 113 $\mathrm{cm}^{2}$ per side. In each experiment, two plates were used in the electrochemical reactor and the distance (d) between plates was varied from $2-4 \mathrm{~cm}$. The electrodes were placed using a monopolar configuration with a total anodic or cathodic surface area (S) of $450 \mathrm{~cm}^{2}$.

Table 2. Reactor and Electrodes Characteristics

\begin{tabular}{ll}
\hline \multicolumn{1}{c}{ Reactor Characteristics } & \multicolumn{1}{c}{ Specification } \\
\hline Material & Plexiglass \\
Size & $250 \mathrm{~mm} \times 250 \mathrm{~mm} \times 300 \mathrm{~mm}$ \\
Reactor mode & Batch \\
Reactor Volume & $18 \mathrm{~L}$ \\
Working volume & $7 \mathrm{~L}$ \\
DC power supply & \\
Voltage range (V) & $0-30$ \\
Current range (A) & $0-2$ \\
Electrode & \\
Material & Aluminum \\
Size & $300 \mathrm{~mm}^{2} \times 150 \mathrm{~mm} \times 2 \mathrm{~mm}$ \\
Anode surface area & $113 \mathrm{~m}^{2}$ \\
Connection arrangement & Parallel type \\
\hline
\end{tabular}

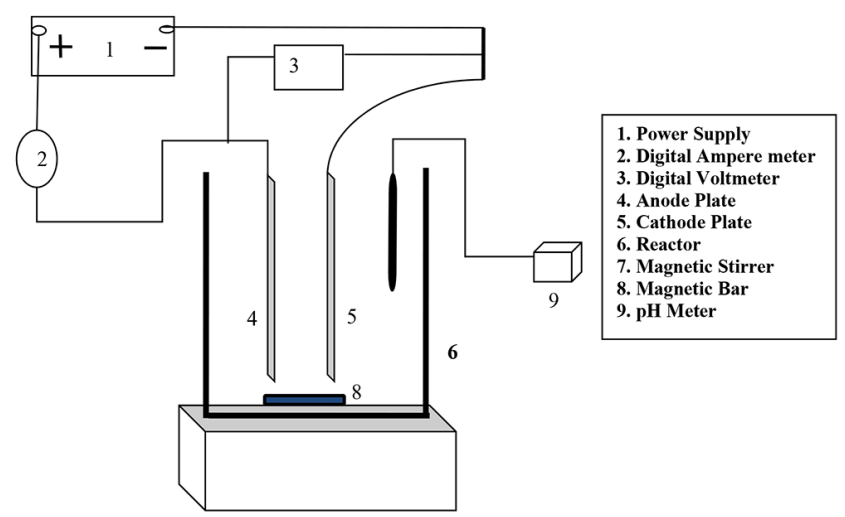

Fig. 1. Schematic diagram of electro chemical cell for removal of metals and TSS.
The current values were selected from $150 \mathrm{~mA}$ to $600 \mathrm{~mA}$ corresponding to a current density from $1.3 \mathrm{~mA} / \mathrm{cm}^{2}$ to $5.3 \mathrm{~mA} / \mathrm{cm}^{2}$ using a precision DC power supply (Microtech agencies Dhanbad, India) characterized by the ranges 0-2 A for current and 0-30 $\mathrm{V}$ for voltage. Before each experiment, the electrodes were polished with abrasive paper to get rid of any oxide film and then thoroughly rinsed.

To pursue the progress during treatment, $10 \mathrm{~mL}$ samples were periodically taken from the container at predetermined time intervals (10 to $40 \mathrm{~min}$ ) and were filtered using Whatman filter paper of grade 42 (GE Healthcare UK Limited) to sort out the sludge from the solution to be dissected. The residual concentrations of metal ions were determined using an atomic absorption spectrophotometer (FAAS-GBC Avanta, Australia) according to APHA standard 2012 [11]. The $\mathrm{pH}$ was continuously measured in the 18-L container and was not adjusted during the treatment. All experiments were performed at room temperature.

\subsection{Calculations}

The amount of electrical energy used is an important economical parameter in the EC process [10]. This parameter is computed by Eq. (1):

$$
E=\frac{U I T}{V}
$$

$E$ is the electrical energy used (in $\mathrm{kWh} / \mathrm{m}^{3}$ ), $U$ is the voltage applied (in V), $I$ is the current (in A), $T$ is the coagulation time in hours. $V$ is the volumes in liters. The amount of sacrificed electrode use is determined by measuring the initial and eventual weight of the electrodes.

The percentage removal efficiency of EC process was computed as a function of operating time by Eq. (2):

Removal efficiency, \%

$$
R_{E}=\frac{C_{0}-C_{t}}{C_{0}} \times 100
$$

Where $C_{0}$ and $C_{t}$ are heavy metal concentrations for each heavy metal and TSS at times 0 and t.

For kinetic study, first order and second order kinetic model were considered to describe for the removal rate [12]. The EC batch process, the mass conservation of pollutants ion is:

$$
-\frac{d C}{d t}=-r_{D}
$$

Where $\left(r_{D}\right)$ is the removal rate in $\mathrm{ppm} / \mathrm{min}$ and $\mathrm{t}$ is EC time in min. With the first-order model $\left(r_{D}=k_{1} C\right)$, the integration of Eq. (3) at the initial concentration $\mathrm{C}(0)=\mathrm{C}_{0}$, gives

$$
C(t)=C_{0} e^{-k_{1} t}
$$

Where $k_{1}$ is the first-order rate constant in $\min ^{-1}$. For the second order model $\left(-r_{D}=k_{2} C^{2}\right)$, the time-dependent concentration is obtained as: 


$$
\frac{1}{C(t)}=\frac{1}{C_{0}}+k_{2} t
$$

Where $k_{2}$ is the second-order rate constant in $\mathrm{ppm}^{-1} \mathrm{~min}^{-1}$.

\section{Results and Discussion}

\subsection{Establishment of Metals Concentration and Other Water Characteristics}

To evaluate the EC performance, synthetic water was prepared with initial concentration of TSS and heavy metals concentration which imparted a sufficient electrical conductivity, total dissolved solids (TDS), turbidity in water samples. The $\mathrm{pH}$ of the synthetic water drops down, which again adjusted as per experimental requirement during the establishment of physiochemical characteristics (Table 3). The $\mathrm{pH}$ of the solution was adjusted by adding either $0.1 \mathrm{~N} \mathrm{NaOH}$ or $0.1 \mathrm{~N} \mathrm{HCl}$ solution.

\subsection{TSS Removal}

The relationship between the TSS removal efficiency and contact time for $\mathrm{pH} 7$ at $30 \mathrm{~min}$ operating time of EC process is depicted in Fig. 3 in which maximum removal occurred at $2 \mathrm{~cm}$ electrode distance. The synthetic water of the initial value of TSS is 135 mg/L is used for experiments The Fig. 2 depicts that as the contact time increased from $10 \mathrm{~min}$ to $40 \mathrm{~min}$ removal efficiency increased from $62.1 \%$ to $76.6 \%$. The removal efficiency, increased up to $30 \mathrm{~min}$ of contact time and beyond that no further significant increased was observed. Bukhari [13] also demonstrated same observation at current $0.2 \mathrm{~A}$ which has supported removal of TSS was significantly consistent after $30 \mathrm{~min}$ of process time [14]. The maximum removal of suspended solids removed in first 10 min after that suspended solids removed in smaller ratios are indicated in the Fig. 2, which was also reported by Aji et al. [4], for first $15 \mathrm{~min}$ after that removal was consistent and also similar results has been also reported by Chou et al. [15] for colour removal efficiency in 20 min of process time (at least $80 \%$ ) and $53-99 \%$ of the initial concentration of zinc and copper decreased within 15-30 min of processing reported by Bazrafshan et al. [16]. The maximum removal efficiency of TSS was observed $(>76 \%)$ after $40 \mathrm{~min}$ of operating time at current density $5.3 \mathrm{~mA} / \mathrm{cm}^{2}$ from synthetic water in this study. The efficiency of TSS removal was increased with an increase in current density from $46.6 \%$ at $1.3 \mathrm{~mA} / \mathrm{cm}^{2}$ till it reaches $76.6 \%$ at $5.3 \mathrm{~mA} / \mathrm{cm}^{2}$. Beyond 5.3 $\mathrm{mA} / \mathrm{cm}^{2}$ no further TSS removal was observed. Such lower removal efficiency for suspended solids was bubble formation mechanism in the reactor [17] investigated that the bubbles formed by EC were not sufficient for a high removal efficiency of suspended solids. The reason that affects bubble size and generation is that

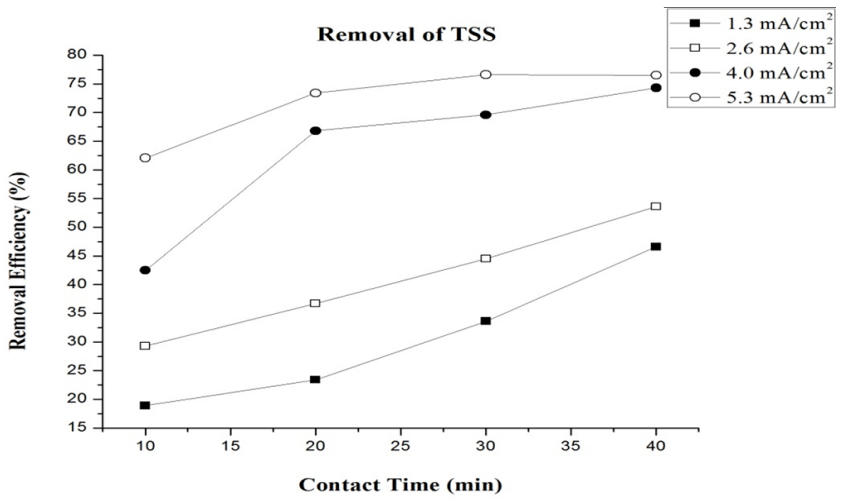

Fig. 2. Removal of TSS along with contact time at different current density and at $\mathrm{pH} 7$, electrode distance $2 \mathrm{~cm}$.

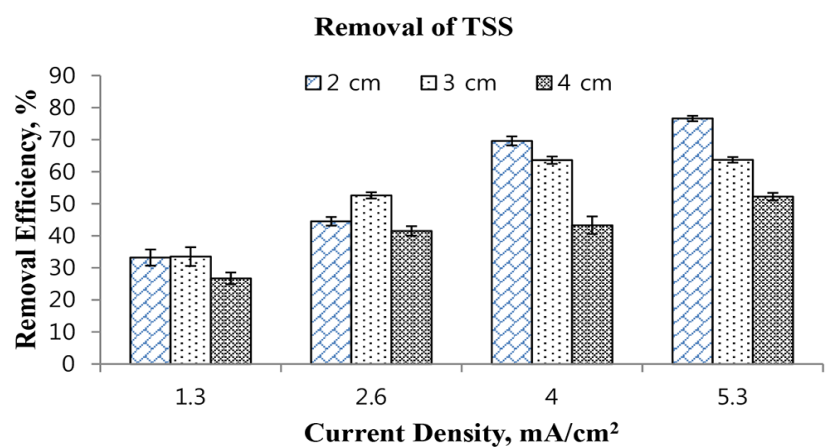

Fig. 3. The relationship between TSS removal efficiency and current density at $\mathrm{pH} \mathrm{7,} \mathrm{different} \mathrm{electrode} \mathrm{distances,} \mathrm{contact} \mathrm{time} 30 \mathrm{~min}$.

the electrode surface, due to the passivation, has a rough surface, which provides larger adhering forces to bubbles than smooth surfaces, thus decreasing their generation.

\subsection{Effect of $\mathrm{pH}$}

According to literature study, it was found that at neutral $\mathrm{pH}$ of 7 , all the metals demonstrated optimal and consistent removal efficiency [18], so $\mathrm{pH} 7$ was established in this study for experimentation. Duration of the process was $40 \mathrm{~min}$ and after every $10 \mathrm{~min} \mathrm{pH}$ of the solution has been checked using a digital $\mathrm{pH}$ meter was found that $\mathrm{pH}$ changes from its initial value as indicated in Fig. 4. At the end of the process $\mathrm{pH}$ has been reached to a value of 7.34, 7.77 and 7.88, respectively, for different interelectrode distances $(2-4 \mathrm{~cm})$. In EC where the $\mathrm{Al}$ electrode is used, it has been observed that at passably basic ambience, $\mathrm{Al}(\mathrm{OH})_{3}$ precipitation occurs and the sweep-flock mechanism dominates [19]. Maximum variation was observed at a lower interelectrode distance $(2 \mathrm{~cm})$ while at another distance $\mathrm{pH}$ of water had less variation. Chen et al. [15] advocated that in the presence of anions such as chloride or sulphate, aluminum hydroxide can exchange with these

Table 3. Physiochemical Characteristics of Synthetic Water Used

\begin{tabular}{cccccccc}
\hline Initial $\mathbf{p H}$ & $\begin{array}{c}\text { Electrical conductivity } \\
(\boldsymbol{\mu S} / \mathbf{c m})\end{array}$ & $\begin{array}{c}\text { Salinity } \\
(\mathbf{p p t})\end{array}$ & $\begin{array}{c}\text { TDS } \\
(\mathbf{p p m})\end{array}$ & $\begin{array}{c}\text { Turbidity } \\
(\mathbf{N T U})\end{array}$ & $\begin{array}{c}\text { TSS } \\
(\mathbf{m g} / \mathbf{L})\end{array}$ & $\begin{array}{c}\text { Colour } \\
(\mathbf{m g} / \mathbf{L})\end{array}$ \\
\hline 3.2 & 1,055 & 592 & 748 & 33 & 135 & Yellowish & 10 \\
\hline
\end{tabular}




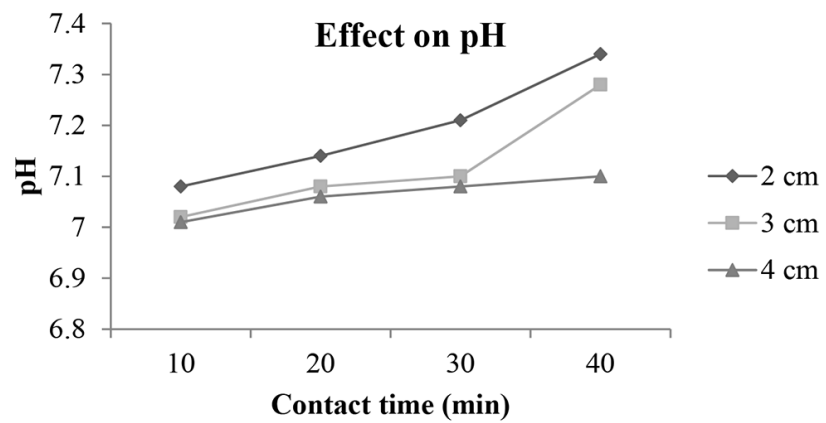

Fig. 4. Change in $\mathrm{pH}$ value during experiments at various electrode distances.

ions thus releasing hydroxyl ions and raising $\mathrm{pH}$. The fact behind this mechanism that the generated metal hydroxides which act as the flocs and remove the pollutant by sedimentation get degraded by collision with each other due to high electrostatic attraction [20].

\subsection{Effect of Current Density}

In all EC processes, current density is the most important parameter for controlling the reaction rate within the electrochemical reactor and adjusts bubble production and its size and distribution. It has been found that as current density increases the removal rate of pollutants also increases [17, 21]. Higher metal removal efficiency accomplished by using electrocoagulation-flotation (ECF) with iron electrodes results from its capability of simultaneously inducing several processes (metal deposition on the cathode, precipitation, and co-precipitation of metals) and, more importantly, from the high sorption capacity of polymeric iron hydroxides generated by the anodic dissolution $[14,22]$. The current density is expected to exhibit a strong effect on the removal efficiency [23-25] especially on the kinetics of heavy metals removal: the higher the current, the more efficient the ECF treatment. An increase in current density from 1.3 to $5.3 \mathrm{~mA} / \mathrm{cm}^{2}$ yields an increase in the efficiency of chromium, copper and zinc removal for aluminum electrode. At a high current density, the extent of anodic dissolution of aluminum increases, resulting in a greater amount of precipitate and removal of copper, zinc and nickel [26].

In this study it has likewise been noticed during a process that hydrogen bubble production was more and small in size that helps to accumulate the pollutants at upper surface at high current density. Flocs deposited on the surface of the water easily removed and sludge generated was less in quantity at the bottom of reactor as such condition.

\subsection{Heavy Metals Removed}

In this study the experiments conducted for 40 min contact time at different current density and electrode distances. Here chromium, copper and zinc removal percentages at different time and current density have been studied. Chromium, Copper and zinc initial concentration in water were $10 \mathrm{mg} / \mathrm{L}$ before the experiment.

The more current density was applied, the more $\mathrm{Al}^{3+}$ and $\mathrm{OH}$ were dosed into the ECF system and the faster the metal concentrations decreased. In addition, the rate of bubble generation increases and the bubble size decreases with the increase of current

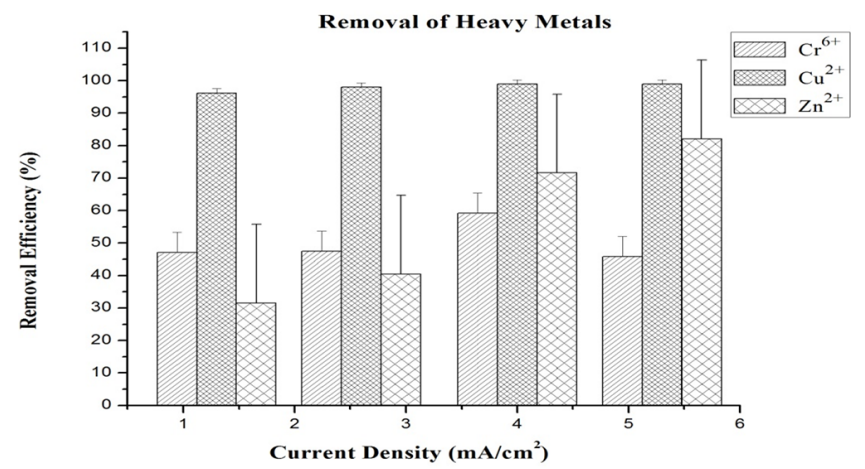

Fig. 5. Variation of percentage removal efficiencies of heavy metals with current density after $40 \mathrm{~min}$ of EC process time of $7 \mathrm{~L}$ synthetic water (Inter electrode distance $3 \mathrm{~cm}$, and $\mathrm{pH}$ 7).

density. Both of these trends are benign in terms of high pollutant removal efficiency by $\mathrm{H}_{2}$ flotation [9]. By observing the impact of EC operating time on the removal efficiency of metals from the waste synthetic water, it was observed that removal efficiency increases with the increase of electrolysis time, which is in accordance with the results of other authors [8, 27]. According to this work, the highest chromium removal efficiency ( $>59 \%$ ) was obtained after $40 \mathrm{~min}$ under the condition of $4 \mathrm{~mA} / \mathrm{cm}^{2}$ of current density (Fig. 5). Some authors found that the $\mathrm{pH}$ of the solution has a significant effect on the Cr(VI) removal efficiency [28-30]. The findings show that ions of chromium(VI) change into $\mathrm{Cr}^{3+}$ during the reaction that occurs around the cathode, and then the ions of $\mathrm{Cr}^{3+}$ are combined with the $\mathrm{OH}^{-}$resulted from water hydrolysis and $\mathrm{Cr}(\mathrm{OH})_{3}$ is produced. When $\mathrm{pH}$ is kept between 3 and 7 , cations of $\mathrm{Al}^{3+}$ around the anode produce polymeric species such as $\mathrm{Al}_{13} \mathrm{O}_{4}(\mathrm{OH})_{24}{ }^{7+}$ that leads to the effective removal of ions of $\mathrm{Cr}^{3+}$ via a sweep coagulation process [29]. Zewail and Yousef [31] demonstrated the effect of $\mathrm{pH}$ on \% removal of $\mathrm{Cr}^{3+} \& \mathrm{Cr}^{6+}$ and found maximum \% removal of $\mathrm{Cr}^{3+}$ occurs at $\mathrm{pH}$, whereas the maximum \% removal of $\mathrm{Cr}^{6+}$ occurs at $\mathrm{pH}$ 4.5. The copper removal efficiency ( $>$ 99\%) was obtained after $40 \mathrm{~min}$ by using an interelectrode distance of $3 \mathrm{~cm}$ and current density of $4 \mathrm{~mA} / \mathrm{cm}^{2}$. In the case of zinc, the removal efficiency ( $>82 \%$ ) at $5.3 \mathrm{~mA} / \mathrm{cm}^{2}$ for $3 \mathrm{~cm}$ was achieved after $40 \mathrm{~min}$ (Fig. 5). A shorter interelectrode distance is desirable, because the electrical resistance (IR drop) increases with the interelectrode distance increase [32]. By increasing the interelectrode distance, less interaction of heavy metals with hydroxide polymers of aluminum is expected [33]. According to the Cu-Pourbaix diagram, copper is solid in the form of $\mathrm{Cu}(\mathrm{OH})_{2}$ at $\mathrm{pH}$ approximately > 4.5 until $\mathrm{pH}$ 14. The Zn-Pourbaix diagram shows that zinc is solid as $\mathrm{ZnO}$ at $\mathrm{pH}$ between 7 and 14 [4]. Removal of copper and zinc has been investigated higher as per Pourbaix diagrams indicates $\mathrm{pH} 7$ suitable for such higher removal, but zinc pourbaix diagrams indicate stability of oxide of zinc due which zinc found in stable passive phase at temperature range reported in revised pourbaix diagrams of zinc [34].

The results can be explained by the flotation of hydrogen bubbles produced at the cathode, which produce more stable flocks when the interelectrode distance was $3.0 \mathrm{~cm}$. The lowest interelectrode distances obstruct the adequate mass transport in the ECF cell, thus 
Table 4. Predicted Parameters of First- and Second-order Removal Rates of Heavy Metal lons at Different Current Densities with Solution Volume $=7,000 \mathrm{~mL}$, and $\mathrm{pH}=7$

\begin{tabular}{|c|c|c|c|c|c|}
\hline Pollutants & $\begin{array}{l}\text { Current density } \\
\left(\mathrm{mA} / \mathrm{cm}^{2}\right)\end{array}$ & $\begin{array}{c}\text { First order kinetic, } \\
\mathrm{dC} / \mathrm{dt}=\mathrm{k}_{1} \mathrm{C}, \mathrm{K}_{1}\left(\min ^{-1}\right)\end{array}$ & $\begin{array}{l}\text { Coeff. of Determination } \\
\qquad\left(\mathrm{R}^{2}\right)\end{array}$ & $\begin{array}{l}\text { Second order kinetic, } \\
-\mathrm{dC} / \mathrm{dt}=\mathrm{k}_{2} \mathrm{C}^{2}, \mathrm{k}_{2} \\
\left(\mathrm{ppm}^{-1} \mathrm{~min}^{-1}\right)\end{array}$ & $\begin{array}{l}\text { Coeff. of Determination } \\
\qquad\left(\mathrm{R}^{2}\right)\end{array}$ \\
\hline \multirow{4}{*}{$\mathrm{Cr}$} & 1.3 & 0.015 & 0.7802 & 0.0022 & 0.6748 \\
\hline & 2.6 & 0.016 & 0.8606 & 0.0022 & 0.0001 \\
\hline & 4 & 0.022 & 0.8491 & 0.0036 & 0.8260 \\
\hline & 5.3 & 0.015 & 0.8528 & 0.0021 & 0.8301 \\
\hline \multirow{4}{*}{$\mathrm{Cu}$} & 1.3 & 0.08 & 0.7724 & 0.0632 & 0.3267 \\
\hline & 2.6 & 0.081 & 0.1488 & 0.063 & 0.8253 \\
\hline & 4 & 0.115 & 0.6740 & 0.247 & 0.6435 \\
\hline & 5.3 & 0.115 & 0.7456 & 0.247 & 0.1089 \\
\hline \multirow{4}{*}{$\mathrm{Zn}$} & 1.3 & 0.009 & 0.5538 & 0.0011 & 0.5400 \\
\hline & 2.6 & 0.017 & 0.7684 & 0.0017 & 0.8813 \\
\hline & 4 & 0.031 & 0.3768 & 0.0063 & 0.1255 \\
\hline & 5.3 & 0.043 & 0.8824 & 0.0114 & 0.3218 \\
\hline \multirow{4}{*}{ TSS } & 1.3 & 0.0156 & 0.2909 & 0.00016 & 0.0076 \\
\hline & 2.6 & 0.019 & 0.7529 & 0.00021 & 0.6112 \\
\hline & 4 & 0.033 & 0.8869 & 0.00053 & 0.0751 \\
\hline & 5.3 & 0.036 & 0.9560 & 0.00059 & 0.9998 \\
\hline
\end{tabular}

Table 5. Consumption of Electrical Energy during Experiments at Different Time Conditions

\begin{tabular}{|c|c|c|c|c|c|}
\hline \multirow{2}{*}{ Voltage, (Volt) } & \multirow{2}{*}{ Current, (Amp) } & \multicolumn{4}{|c|}{ Electrical energy consumption $\left(\mathrm{kW} \mathrm{h} / \mathrm{m}^{3}\right)$} \\
\hline & & $10 \mathrm{~min}$ & $20 \min$ & $30 \mathrm{~min}$ & $40 \min$ \\
\hline 6.3 & 0.150 & 0.0216 & 0.0445 & 0.067 & 0.089 \\
\hline 8.6 & 0.300 & 0.058 & 0.121 & 0.184 & 0.243 \\
\hline 14.3 & 0.450 & 0.141 & 0.303 & 0.459 & 0.606 \\
\hline 16.6 & 0.600 & 0.227 & 0.469 & 0.711 & 0.939 \\
\hline
\end{tabular}

reducing removal efficiency rates. This behavior indicates the proportional importance of water movement and turbulence along the handling time and their great dependence on the interelectrode space.

\subsection{Effect on Electrical Conductivity}

Electrical conductivity is the ability of the solution to conduct electrical current between two electrodes. This electrical conductivity seems to affect more directly the voltage or the current intensity. During the EC process, it has been observed that the electrical conductivity of the solution in the reactor fluctuated in decreasing order due which TDS also changed. It had fluctuated $5-6 \%$ of its initial value. Decreasing the conductivity of the solution resulted in enhance of the cell voltage.

\subsection{Effect of EC Time and Kinetic Study}

In this work, the kinetic study for the removal of pollutants was considered for various current densities at the ambient temperature and constant synthetic water volume. The squared-correlation coefficient, $\mathrm{R}^{2}$, was used to measure the goodness of the kinetic model. The kinetic parameters of both first- and second-order models together with the $\mathrm{R}^{2}$ values are given in Table 4 . At current density of $5.3 \mathrm{~mA} / \mathrm{cm}^{2}$, the $\mathrm{R}^{2}$ values that correspond to both kinetic models were found close to unity for all heavy metals and TSS.
Only first-order kinetic model can describe the removal rate of chromium ions $\left(\mathrm{Cr}^{3+}\right)$ at lower current density. The copper and zinc ions were the only heavy metal ions that their removal rate can be modeled by first- and second-order kinetics since the corresponding $\mathrm{R}^{2}$ value at a lower current density was close to unity. In case of total suspended solids only for both kinetics modeled corresponding coefficient of determination, $\mathrm{R}^{2}$ were close to unity at higher current density i.e. $5.3 \mathrm{~mA} / \mathrm{cm}^{2}$.

\subsection{Electrical Energy Consumption}

The amount of energy consumed is an important economic parameter in the EC process. The majority of operating costs is also related to the amount of electrical energy used. Also in this study the amount of energy used for metals and TSS removal was evaluated as a function of time in different current densities and potential. When the current density increases from $1.3 \mathrm{~mA} / \mathrm{cm}^{2}$ to $5.3 \mathrm{~mA} / \mathrm{cm}^{2}$ (0.150-600 A), the energy consumption increased slightly. Results showed that increase in current leads to increase in energy consumption due to polarization and increase in the number of aluminum compounds, which elevate the efficiency of metals and TSS removal as well.

Therefore, in order to reach an optimum current density, it's necessary to evaluate both the removal percent and the amount of electrical energy used [7, 8, 21, 26, 33] as depicted in Table 5. 
The electrical energy, $0.459 \mathrm{kWh} / \mathrm{m}^{3}$ has been consumed to achieve $99 \%, 59.2 \%$ and $71.6 \%$ removal of $\mathrm{Cu}, \mathrm{Cr}$ and $\mathrm{Zn}$ respectively for $30 \mathrm{~min}$ process time. Moreover, beyond $4.0 \mathrm{~mA} / \mathrm{cm}^{2}$ current density (0.450 A current) no significant removal was observed as shown in Fig. 3 and Fig. 5.

\section{Conclusions}

In this work, EC treatment using aluminum sacrificial electrodes for a synthetic water containing $\mathrm{Cu}, \mathrm{Cr}$, and $\mathrm{Zn}$ heavy metals were investigated. Effects of current density, operating time, and initial $\mathrm{pH}$ on the removal efficiency were examined in a parallel plate electrochemical reactor.

This study has concluded that experimentally as well as kinetic modeling has given high removal rate for all metals and TSS at higher current density except copper metals which give the same results at lower current density. During experiments, it was observed that $\mathrm{pH}$ of water increased more at lower current.

In this study concluded that current density required for efficient removal of heavy metals is lower at minimum time $30 \mathrm{~min}$ of process except zinc. Here it has been observed removal efficiency almost same for electrode distance $2 \mathrm{~cm}$ or $3 \mathrm{~cm}$ and operating time $30 \mathrm{~min}$ to $40 \mathrm{~min}$.

In the context of sludge generated study shows that the sludge accumulates on the top layer of solution is more in comparison of the bottom of the reactor. Sludge generated is less at bottom at high current density. In the case of energy consumption, it was concluded that $0.459 \mathrm{kWh} / \mathrm{m}^{3}$ is sufficient for $99 \% \mathrm{Cu}, 59 \%$ $\mathrm{Cr}$ and $71 \%$ of $\mathrm{Zn}$ up to $30 \mathrm{~min}$ of treatment time for which 0.450 A current is required.

Granting to the closing remarks, EC using monopolar aluminum electrodes is convenient and less power consumption for effective removal of heavy metals from synthetic water and achieves faster removal of pollutants in comparison to chemical coagulation, where several hours are needed.

\section{Acknowledgements}

We would wish to get hold of this chance to convey our sincere gratitude to TEQIP -II for funding this research study. We are immensely grateful to the Department of Environmental Science and Engineering, Indian School of Mines for their unconditional support and encouragement. We are indebted to all researchers who have guided us with their valuable data and info.

\section{Nomenclature}

$C_{0} \quad$ Initial concentration of the heavy metals and TSS (mg/L)

$C_{t} \quad$ Concentration of after $\mathrm{t}$ time in minute $(\mathrm{mg} / \mathrm{L})$

$D \quad$ Distance between electrodes (mm)

E Electrical energy consumption $\left(\mathrm{kWh} / \mathrm{m}^{3}\right)$

F Faraday' constant, 96,500 C/mol

I Current used in EC process (ampere)

\section{References}

1. Valipour M. Drainage, waterlogging, and salinity. Arch. Agron. Soil Sci. 2014;60:1625-1640.

2. Valipour M. Future of agricultural water management in Africa. Arch. Agron. Soil Sci. 2015;61:907-927.

3. Rajeshwar K, Ibanez J, Swain GM. Electrochemistry and the environment. J. Appl. Electrochem. 1994;24:1077-1091.

4. Aji B, Yavuz Y, Koparal AS. Electrocoagulation of heavy metals containing model wastewater using monopolar iron electrodes. Sep. Purif. Technol. 2012;86:248-254.

5. Mansoorian HJ, Mahvi AH. Removal of lead and zinc from battery industry wastewater using electrocoagulation process: Influence of direct and alternating current by using iron and stainless steel rod electrodes. Sep. Purif. Technol. 2014;135: 165-175.

6. Kobya M, Can OT, Bayramoglu M. Treatment of textile wastewaters by electrocoagulation using iron and aluminum electrodes. J. Hazard. Mater. 2003;100:163-178.

7. Heidmann I, Calmano W. Removal of Zn(II), Cu(II), Ni(II), $\mathrm{Ag}(\mathrm{I})$ and $\mathrm{Cr}(\mathrm{VI})$ present in aqueous solutions by aluminium electrocoagulation. J. Hazard. Mater. 2008;152:934-941.

8. Mouedhen G, Feki M, De Petris Wery M, Ayedi HF. Behavior of aluminum electrodes in electrocoagulation process. J. Hazard. Mater. 2008;150:124-135.

9. Akbal F, Camci S. Comparison of electrocoagulation and chemical coagulation for heavy metal removal. Chem. Eng. Technol. 2010;33:1655-1664.

10. Ferreira ADM, Marchesiello M, Thivel PX. Removal of copper, zinc and nickel present in natural water containing $\mathrm{Ca}^{2+}$ and $\mathrm{HCO}^{-3}$ ions by electrocoagulation. Sep. Purif. Technol. 2013;107:109-117.

11. Rice EW, Baird RB, Eaton AD, Clesceri LS. Standard methods for the examination of water and wastewater. 22nd ed. Washington D.C.: APHA/AWWA/WPCF; 2012.

12. Shannag MA, Qodah KA, Melhem KB, Qtaishat MR, Alkasrawi M. Heavy metal ions removal from metal plating wastewater using electrocoagulation: Kinetic study and process performance. Chem. Eng. J. 2015;260:749-756.

13. Bukhari AA. Investigation of the electro-coagulation treatment process for the removal of total suspended solids and turbidity from municipal wastewater. Bioresource Technol. 2008;99: 
914-921.

14. Adhoum N, Monser L, Bellakhal N, Belgaied J. Treatment of electroplating wastewater containing $\mathrm{Cu}^{2+}, \mathrm{Zn}^{2+}$ and $\mathrm{Cr}(\mathrm{VI})$ by electrocoagulation. J. Hazard. Mater. 2004;112:207-213.

15. Chou WL, Wang CT, Chang CP. Comparison of removal of Acid Orange 7 by electrooxidation using various anode materials. Desalination 2011;266:201-207.

16. Bazrafshan E, Mahvi AH, Zazouli MA. Removal of zinc and copper from aqueous solutions by electrocoagulation technology using iron electrodes. Asian J. Chem. 2011;23:5506-5510.

17. Chen G, Chen PX, Yue L. Electrocoagulation and electroflotation of restaurant wastewater. J. Environ. Eng. 2000;126:858-863.

18. Drouichea N, Aoudj S, Lounici H, Drouiche M, Ouslimane T, Ghaffour N. Fluoride removal from pretreated photovoltaic wastewater by electrocoagulation: An investigation of the effect of operational parameters. Proced. Eng. 2012;33:385-391.

19. Gures A, Yalcin M, Dogar C. Electrocoagulation of some reactive dyes: A statistical investigation of some electrochemical variables. Waste Manage. 2002;22:491-499.

20. Daneshvar N, Sorkhabi HA, Kasiri MB. Decolorization of dye solution containing Acid Red 14 by electrocoagulation with a comparative investigation of different electrode connections. J. Hazard. Mater. 2004;112:55-62.

21. Ghosh D, Solanki H, Purkait MK. Removal of Fe(II) from tap water by electrocoagulation technique. J. Hazard. Mater. 2008;155:135-143.

22. Meunier N, Drogui P, Gourvenec C, Mercier G, Hausler R, Blais JF. Removal of metals in leachate from sewage sludge using electrochemical technology. Environ. Technol. 2004;25:235-245.

23. Mollah MYA, Morkovsky P, Gomes JAG, Kesmez M, Parga J, Cocke DL. Fundamentals, present and future perspectives of electrocoagulation. J. Hazard. Mater. 2004;114:199-210.

24. Holt PK, Barton GW, Mitchell CA. The future for electrocoagulation as a localised water treatment technology. Chemosphere 2005;59:355-367.
25. Can OT, Kobya M, Demirbas E, Bayramoglu M. Treatment of the textile wastewater by combined electrocoagulation. Chemosphere 2006;62:181-187.

26. Merzouk B, Gourich B, Sekki A, Madani K, Chibane M. Removal turbidity and separation of heavy metals using electrocoagulation-electro flotation technique : A case study. J. Hazard. Mater. 2009;164:215-222.

27. Solak M, Kiliç M, Huseyin Y, Şencan A. Removal of suspended solids and turbidity from marble processing wastewaters by electrocoagulation: Comparison of electrode materials and electrode connection systems. J. Hazard. Mater. 2009;172:345-352.

28. Verma SK, Khandegar V, Saroha AK. Removal of chromium from electroplating industry effluent using electrocoagulation. J. Hazard. Toxic. Radio. Waste 2013;17:146-152.

29. Dermentzis K, Christoforidis A, Valsamidou E. Removal of nickel, copper, zinc and chromium from synthetic andindustrial wastewater by electrocoagulation. Int. J. Environ. Sci. 2011;1:697-710.

30. Kashefi Asl M, Moshtaghib M, Hassani AH. Efficiency evaluation of electrocoagulation process for removal of chromium (heavy metal) from municipal and industrial wastewater Indian J. Sci. Res. 2014;7:1258-1268.

31. Zewail TM, Yousef NS. Chromium ions $\left(\mathrm{Cr}^{6+} \& \mathrm{Cr}^{3+}\right)$ removal from synthetic wastewater by electrocoagulation using vertical expanded Fe anode. J. Electr. Chem. 2014;735:123-128.

32. Mohora E, Roncevic S, Dalmacija B, et al. Removal of natural organic matter and arsenic from water by electrocoagulation/flotation continuous flow reactor. J. Hazard. Mater. 2012;235:257-264.

33. Modirshahla N, Behnajadya MA, Mohammadi SA. Investigation of the effect of different electrodes and their connections on the removal efficiency of 4-nitrophenol from aqous solution by electrocoagulation. J. Hazard. Mater. 2008;154:778-786.

34. Beverskogt B, Puigdomenech I. Revised pourbaix diagrams for zinc at $25-300^{\circ}$ C. Corrosion Sci. 1997;39:107-114. 